\title{
Roles of chlorpropamide, alcohol and acetaldehyde in determining the chlorpropamide-alcohol flush
}

\author{
L. Groop, C. J. P. Eriksson, R. Huupponen, R. Ylikahri and R. Pelkonen
}

Third and Fourth Departments of Medicine, University of Helsinki, Research Laboratories of the State Alcohol Monopoly (ALKO), Helsinki and Department of Pharmacology, University of Turku, Finland

\begin{abstract}
Summary. The value and reproducibility of the chlorpropamide-alcohol flush (CPAF) have been questioned, and objective measures of the test are required. Recording of facial skin temperature, measurement of chlorpropamide, ethanol and acetaldehyde concentrations have been proposed for this purpose. The present study was designed to evaluate the relative contributions of these variables in determining CPAF. Twenty-one Type 2 (non-insulin-dependent) diabetic patients (11 CPAF-positive and 10 CPAF-negative according to previous tests with standard amounts of alcohol and chlorpropamide) were investigated in a random fashion with either chlorpropamide or placebo given on three subsequent evenings before a two-step alcohol challenge with increasing body-weightmatched amounts of alcohol. Higher rises in facial skin temperature and heart rate, higher flush-score and higher acetaldehyde levels resulted from chlorpropamide therapy than followed placebo. After smaller alcohol challenges (with chlorpropamide pretreatment) there were positive intercorrelations between flush-score, rise in facial skin temperature,
\end{abstract}

and plasma concentrations of chlorpropamide and blood acetaldehyde. The increased alcohol dose abolished most of these correlations and a minimum temperature rise of $1.8^{\circ} \mathrm{C}$ appeared in all but two subjects regardless of previous $\mathrm{CPAF}$ classification. During the current experimental conditions, the previously-classified CPAF-positive and CPAF-negative patients did not differ with respect to flush-score, rise in skin temperature, heart rate, blood acetaldehyde or ethanol concentrations, whereas they differed with respect to chlorpropamide concentrations. The present results support the view that CPAF is associated with elevated blood acetaldehyde levels due to inhibition of aldehyde dehydrogenase by chlorpropamide. Thus both alcohol and chlorpropamide concentrations are critical in determining the CPAF. Furthermore, body weight matching in applying the CPAF test is essential.

Key words: Chlorpropamide-alcohol flush, Type 2 diabetes, chlorpropamide, alcohol acetaldehyde, body weight.
Facial flushing after alcohol occurs frequently in Type 2 (non-insulin-dependent) diabetic patients taking chlorpropamide (CP) [1]. It has been suggested that the chlorpropamide-alcohol flush (CPAF) acts as a genetic marker for a special subtype of Type 2 diabetes, characterized by a high frequency of diabetes in the family and relative freedom from diabetic complications [2-5].

However, the reproducibility of the test has been questioned [6] and objective measurements for the recording of the flush have been sought [7]. Since flushing is associated with an increase in facial skin temperature, the recording of cheek temperature has been considered as an objective measurement of the flush. Most investigators have defined a temperature increase of $1{ }^{\circ} \mathrm{C}$ or more as a flush $[2,6]$. This criterion is, however, not universal, since patients can flush without a rise in skin temperature and may have a rise in skin temperature without a visible flush reaction [6].
The mechanism which produces the flush is poorly understood. Some authors have reported higher blood acetaldehyde concentrations in CPAF-positive than in CPAF-negative patients $[8,9]$. It has been suggested that $\mathrm{CP}$ acts as a non-competitive inhibitor of aldehyde dehydrogenase resulting in increased acetaldehyde concentrations [10]. The dose of chlorpropamide required for producing the flush is uncertain. Although Jerntorp et al. [8] reported higher serum concentrations of $\mathrm{CP}$ in CPAF-positive than in CPAF-negative patients, this was contradicted by Barnett et al. [1], who did, however, agree that $\mathrm{CP}$ maintenance therapy resulted in higher levels and a higher prevalence of CPAF in investigated subjects. If CPAF is caused by elevated acetaldehyde levels as a result of inhibited aldehyde dehydrogenase, changes in ethanol levels could also influence the flush. The dependence of the flush on alcohol dose has, however, been challenged [11]. 
Table 1. Differences between the placebo and chlorpropamide periods with respect to recorded variables in 21 Type 2 diabetic patients after ingestion of alcohol $1 \mathrm{ml} / \mathrm{kg}$ body weight (first drink) followed after $45 \mathrm{~min}$ by alcohol $2 \mathrm{ml} / \mathrm{kg}$ (second drink)

\begin{tabular}{|c|c|c|c|c|c|c|c|c|c|c|}
\hline & \multicolumn{2}{|c|}{$\begin{array}{l}\text { Flush score } \\
(0-3)\end{array}$} & \multicolumn{2}{|c|}{$\begin{array}{l}\text { Rise in skin tempera- } \\
\text { ture }\left({ }^{\circ} \mathrm{C}\right)\end{array}$} & \multicolumn{2}{|c|}{$\begin{array}{l}\text { Rise in heart rate } \\
\text { (beats } / \mathrm{min} \text { ) }\end{array}$} & \multicolumn{2}{|c|}{$\begin{array}{l}\text { Blood ethanol } \\
(\mathrm{mmol} / \mathrm{l})\end{array}$} & \multicolumn{2}{|c|}{$\begin{array}{l}\text { Blood acetaldehyde } \\
(u \mathrm{~mol} / 1)\end{array}$} \\
\hline & $\begin{array}{l}\text { First } \\
\text { drink }\end{array}$ & $\begin{array}{l}\text { Second } \\
\text { drink }\end{array}$ & $\begin{array}{l}\text { First } \\
\text { drink }\end{array}$ & $\begin{array}{l}\text { Second } \\
\text { drink }\end{array}$ & $\begin{array}{l}\text { First } \\
\text { drink }\end{array}$ & $\begin{array}{l}\text { Second } \\
\text { drink }\end{array}$ & $\begin{array}{l}\text { First } \\
\text { drink }\end{array}$ & $\begin{array}{l}\text { Second } \\
\text { drink }\end{array}$ & $\begin{array}{l}\text { First } \\
\text { drink }\end{array}$ & $\begin{array}{l}\text { Second } \\
\text { drink }\end{array}$ \\
\hline Placebo & $0.4 \pm 0.1$ & $0.4 \pm 0.1$ & $0.6 \pm 0.2$ & $0.8 \pm 0.2$ & $0.5 \pm 1.1$ & $4.1 \pm 1.5$ & $2.23 \pm 0.20$ & $8.01 \pm 0.74$ & $0.13 \pm 0.11$ & $0.75 \pm 0.21$ \\
\hline $\begin{array}{l}\text { Chlor- } \\
\text { propamide }\end{array}$ & $1.5 \pm 0.2^{c}$ & $2.1 \pm 0.2^{\mathrm{c}}$ & $1.5 \pm 0.3^{\mathrm{a}}$ & $3.1 \pm 0.3^{c}$ & $6.0 \pm 1.0^{b}$ & $10.4 \pm 1.8^{c}$ & $2.45 \pm 0.18$ & $8.90 \pm 0.50$ & $2.70 \pm 0.22^{c}$ & $6.79 \pm 1.43^{\mathrm{c}}$ \\
\hline
\end{tabular}

Results expressed as mean \pm SEM. ${ }^{a} p<0.05 ;{ }^{b} p<0.01 ;{ }^{c} p<0.001$, significance of difference from placebo

The present investigation was designed to study the influence of pharmacokinetics of alcohol and CP on CPAF in Type 2 diabetes.

\section{Materials and methods}

In the 21 patients studied, Type 2 diabetes had been diagnosed after the age of 40 years. Eleven (three males and eight females) were CPAF-positive and ten (seven males and three females) were CPAFnegative. The patients were informed of the risks of the study before their informed consent to participate was obtained. The study protocol was approved by the Ethical Committee of the Helsinki University Hospital. The CPAF-positive patients had a mean \pm SEM age of $56 \pm 2$ years (range 37-64 years), a mean duration of diabetes of $6 \pm 1$ years (range $3-12$ years), and a mean relative body weight $117 \pm 5 \%$ of ideal body weight (range 100\%-135\%) (Metropolitan Life Insurance Tables, 1959). Seven patients were treated with oral anti-diabetic drugs (glibenclamide or glipizide) and four patients with insulin. The CPAF-negative patients had a mean age of $54 \pm 3$ years (range 38-68 years), a mean duration of diabetes of $7 \pm 1$ years (range 2-17 years) and a mean relative body weight $127 \pm 3 \%$ (range $112-147 \%$ ). Seven patients were treated with oral anti-diabetic agents (glibenclamide and glipizide) and three with insulin. The insulin-treated patients had previously been treated for at least 2 years with oral anti-diabetic drugs.

The CPAF reaction had been assessed by the method previously described [2], slightly modified. A rise in facial skin temperature of $1.5^{\circ} \mathrm{C}$ or more was defined as CPAF positivity. The mean rise in facial skin temperature $30 \mathrm{~min}$ after the drink was $2.6 \pm 0.2^{\circ} \mathrm{C}$ for $\mathrm{CPAF}$ positive (range $1.5-3.9^{\circ} \mathrm{C}$ ) and $0.3 \pm 0.2^{\circ} \mathrm{C}$ for $\mathrm{CPAF}-$ negative patients (range $0-1.4^{\circ} \mathrm{C}$ ).

\section{Experimental design}

The patients were given in random order either $250 \mathrm{mg}$ chlorpropamide or placebo on three subsequent evenings. The alcohol was given after breakfast, $12 \mathrm{~h}$ after the previous tablet. Facial temperature was recorded (by a skin thermometer attached $2 \mathrm{~cm}$ below the outer canthus of the left eye) at 5-min intervals from $45 \mathrm{~min}$ before to $75 \mathrm{~min}$ after the first alcohol challenge. The heart rate was recorded simultaneously from the radial pulse. Room temperature was kept constant at $20-20^{\circ} \mathrm{C}$ during the test. The first alcohol challenge (Vinum Medicinale, Oy Alko Helsinki, $12 \% \mathrm{w} / \mathrm{v}$ alcohol for hospital use, $1 \mathrm{ml} / \mathrm{kg}$ body weight which approximates $0.12 \mathrm{~g} / \mathrm{kg}$ absolute alcohol) was given at time 0 and the second alcohol challenge $(2 \mathrm{ml} / \mathrm{kg}$ body weight Vinum Medicinale) 45 min later.

Blood samples for the measurement of acetaldehyde and ethanol concentrations were drawn at 30 and $75 \mathrm{~min}$ after the first drink. Blood for the measurement of plasma CP concentrations was drawn $30 \mathrm{~min}$ after the first alcohol dose. Two technicians, who were not aware of the randomization protocol, tried to estimate the flush by the use of a flush-score $(0=$ no flush, $1=$ uncertain flush, $2=$ certain flush, 3 = strong flush) at 30 and $75 \mathrm{~min}$ after the first alcohol challenge. Two weeks elapsed between the two investigations in each subject.

Blood alcohol and acetaldehyde concentrations were measured by improved whole-blood protein precipitation by perchloric acid and heat space gas chromatography [12]. Plasma chlorpropamide concentrations were measured by high-pressure liquid chromatography [13].

\section{Statistical analysis}

All data are presented as mean \pm SEM. Where appropriate, the difference between and within groups was tested with Student's unpaired and paired t-tests. Correlations were tested with linear regression analysis.

\section{Results}

\section{Comparisons between placebo and chlorpropamide}

The estimated flush-score, rise in facial skin temperature, heart rate and blood acetaldehyde concentration were higher after $\mathrm{CP}$ than after placebo (Table 1). All these changes were accentuated after the second alcohol challenge compared with the reactions after the first alcohol challenge. During placebo, the only difference between the first and the second alcohol challenge was that heart rate increased with increased alcohol dose $(p<0.05)$.

The ethanol concentrations did not significantly differ between the placebo and CP periods. Blood acetaldehyde concentrations during placebo were not significantly different from zero.

\section{Correlations between the recorded variables during CP test}

After both alcohol doses, the flush-score showed a significant positive correlation with the rise in facial skin temperature $(p<0.01)$, blood acetaldehyde concentrations $(p<0.05)$ and plasma CP concentration $(p<0.05$; Fig. 2). In addition, the rise in facial skin temperature was positively correlated after the first alcohol dose with acetaldehyde $(p<0.05)$ and $\mathrm{CP}$ concentration $(p<0.05)$. However, after the second alcohol dose, there was no significant correlation between these variables, 


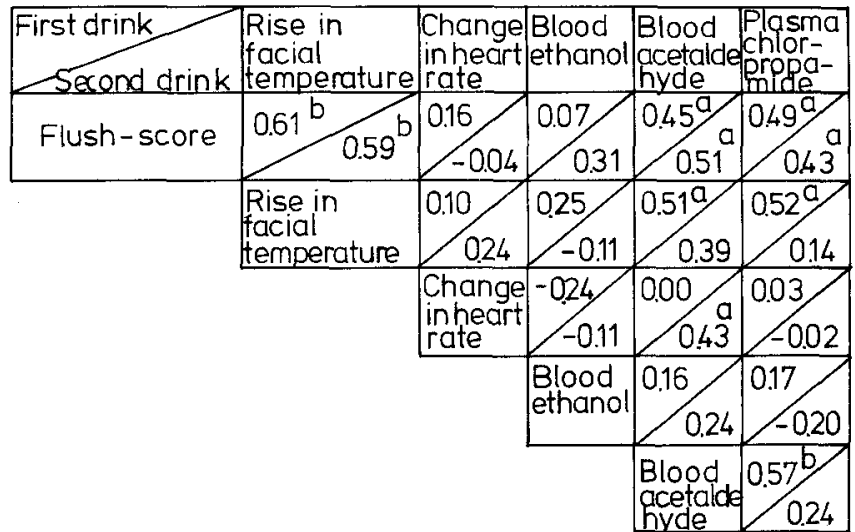

Fig. 1. Correlations between the recorded variables after the two alcohol challenges (chlorpropamide period) in 21 patients with Type 2 diabetes. ${ }^{\mathrm{a}} p<0.05 ;{ }^{\mathrm{b}} p<0.01$

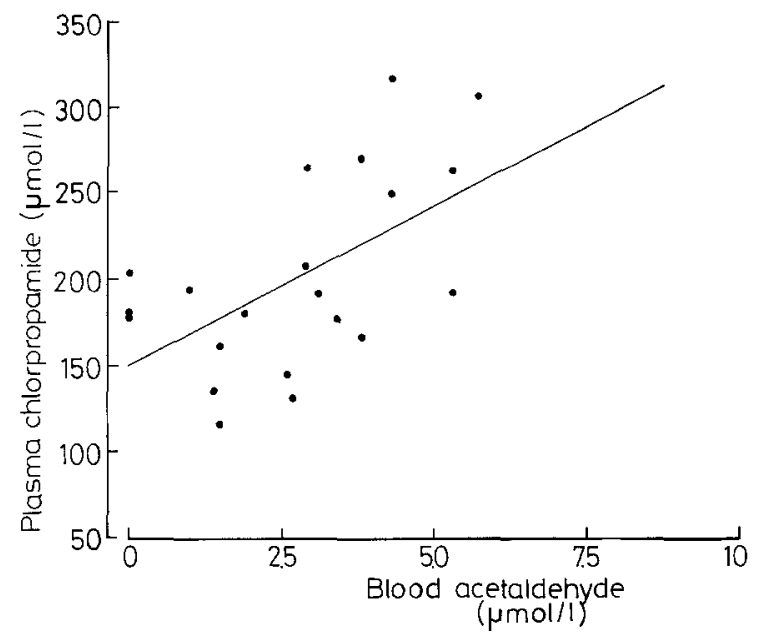

Fig. 2. Correlation between blood acetaldehyde and plasma chlorpropamide after the first alcohol challenge $(1 \mathrm{ml} / \mathrm{kg})$ in 21 Type 2 diabetic patients. Product-moment correlation coefficient $r=0.57, p<$ $0.01, y=152.9+18.7 \times$

although the rise in heart rate correlated positively with blood acetaldehyde concentration $(p<0.05)$. Acetaldehyde and CP concentrations were positively correlated after the first alcohol dose ( $p<0.01$; Figs. 1 and 2), but not after the second.

\section{Comparisons between CPAF-positive and $C P A F-n e g a t i v e$ patients}

There was no correlation between the temperature rise in the previous test and the temperature response to the larger alcohol and chlorpropamide doses (Table 2). Patients previously classified according to the fixed standard amounts of CP and alcohol [2] did not differ in the present experiments with regard to the rise in facial skin temperature (Tables 2 and 3). However, the previously classified CPAF-positive and CPAF-negative patients differed with respect to $\mathrm{CP}$ concentrations $(p<0.05)$. By the use of a temperature level of $1.5^{\circ} \mathrm{C}$ to discriminate
Table 2. Individual rises in facial skin temperature during the previous test and during the current experimental conditions with chlorpropamide or placebo plus alcohol $1 \mathrm{ml} / \mathrm{kg}$ body weight (first drink) or $2 \mathrm{ml} / \mathrm{kg}$ body weight alcohol (second drink)

\begin{tabular}{|c|c|c|c|c|c|c|}
\hline \multirow{3}{*}{$\begin{array}{l}\text { Patient } \\
\text { no }\end{array}$} & \multirow[t]{3}{*}{ Sex } & \multicolumn{5}{|c|}{ Facial skin temperature $\left({ }^{\circ} \mathrm{C}\right)$} \\
\hline & & \multirow{2}{*}{$\begin{array}{l}\text { Previous } \\
\text { test }^{2}\end{array}$} & \multicolumn{2}{|c|}{ Chlorpropamide } & \multicolumn{2}{|c|}{ Placebo } \\
\hline & & & $\begin{array}{l}\text { First } \\
\text { drink }\end{array}$ & $\begin{array}{l}\text { Second } \\
\text { drink }\end{array}$ & $\begin{array}{l}\text { First } \\
\text { drink }\end{array}$ & $\begin{array}{l}\text { Second } \\
\text { drink }\end{array}$ \\
\hline 1 & $\mathbf{M}$ & 2.2 & 1.7 & 2.1 & 0.6 & 0.4 \\
\hline 2 & $\mathrm{M}$ & 1.8 & 4.1 & 4.3 & 1.2 & 1.6 \\
\hline 3 & $\mathrm{~F}$ & 2.6 & 2.2 & 5.4 & 0.5 & -0.2 \\
\hline 4 & $\mathrm{~F}$ & 1.9 & 2.3 & 3.7 & -0.2 & 0.4 \\
\hline 5 & $F$ & 3.0 & 0 & 1.8 & 0.8 & 0.6 \\
\hline 6 & $\mathrm{~F}$ & 2.3 & 2.8 & 3.6 & 0 & 1.0 \\
\hline 7 & $\mathrm{~F}$ & 3.9 & 1.4 & 5.6 & 0.8 & 0.4 \\
\hline 8 & $\mathrm{~F}$ & 2.9 & 0.6 & 2.0 & 0.3 & 1.3 \\
\hline 9 & $\mathrm{~F}$ & 3.3 & 1.8 & 2.6 & 0.4 & 1.0 \\
\hline 10 & $\mathbf{M}$ & 2.6 & 0.8 & 3.1 & 0.9 & 1.0 \\
\hline 11 & $\mathrm{~F}$ & 1.5 & 0.7 & 5.8 & 3.0 & 2.5 \\
\hline 12 & $\mathrm{M}$ & 0 & 0.4 & 2.4 & -1.0 & -1.2 \\
\hline 13 & $\mathbf{M}$ & 1.4 & 1.8 & 2.0 & 1.0 & 1.2 \\
\hline 14 & $\mathbf{M}$ & 0.2 & 0.6 & 1.8 & -0.2 & -1.2 \\
\hline 15 & $F$ & 0.2 & 2.0 & 3.0 & 0.3 & 0.6 \\
\hline 16 & $F$ & 0.2 & 5.2 & 5.2 & 0.6 & 0.4 \\
\hline 17 & $\mathbf{M}$ & 0.7 & 0.2 & 0.4 & 0.8 & 0.6 \\
\hline 18 & $\mathrm{~F}$ & 0.1 & 0.2 & 0.2 & 0.4 & 1.0 \\
\hline 19 & $\mathbf{M}$ & 0 & -0.8 & 2.8 & 0.6 & 1.4 \\
\hline 20 & $\mathbf{M}$ & 0.1 & 1.6 & 3.2 & 0 & 0 \\
\hline 21 & $\mathrm{M}$ & 0 & 1.0 & 2.8 & 1.2 & 1.8 \\
\hline
\end{tabular}

between CPAF-positive and CPAF-negative patients, the patients were re-divided into two groups after the current experiment (Tables 2 and 3). Despite equal alcohol doses per body weight, significant differences in plasma $\mathrm{CP}$ and blood acetaldehyde concentrations $(p<0.05)$ were found between patients typed as CPAFpositive and CPAF-negative in the present experiments (Table 3).

\section{Discussion}

The first step in the elimination of ethanol in the liver is oxidation to acetaldehyde by alcohol dehydrogenase, after which acetaldehyde is metabolized to acetic acid by the enzyme aldehyde dehydrogenase. CP and tolbutamide have been shown to inhibit aldehyde dehydrogenase non-competitively, resulting in increased acetaldehyde levels [10]. The present finding of higher acetaldehyde levels after $\mathrm{CP}$ than after placebo supports this view, since alcohol concentrations were similar during both periods. The positive correlation between CP and acetaldehyde concentrations further supports this mechanism. There is, however, uncertainty whether the flush can be explained solely by a rise in acetaldehyde concentrations. Prostaglandin inhibitors have been shown to attenuate the flush in some patients $[4,14]$ without affecting the increase in blood acetalde- 
Table 3. Differences between CPAF-positive and CPAF-negative patients after the alcohol challenge tests using 1 (first drink) or $2 \mathrm{ml} / \mathrm{kg}$ (second drink)

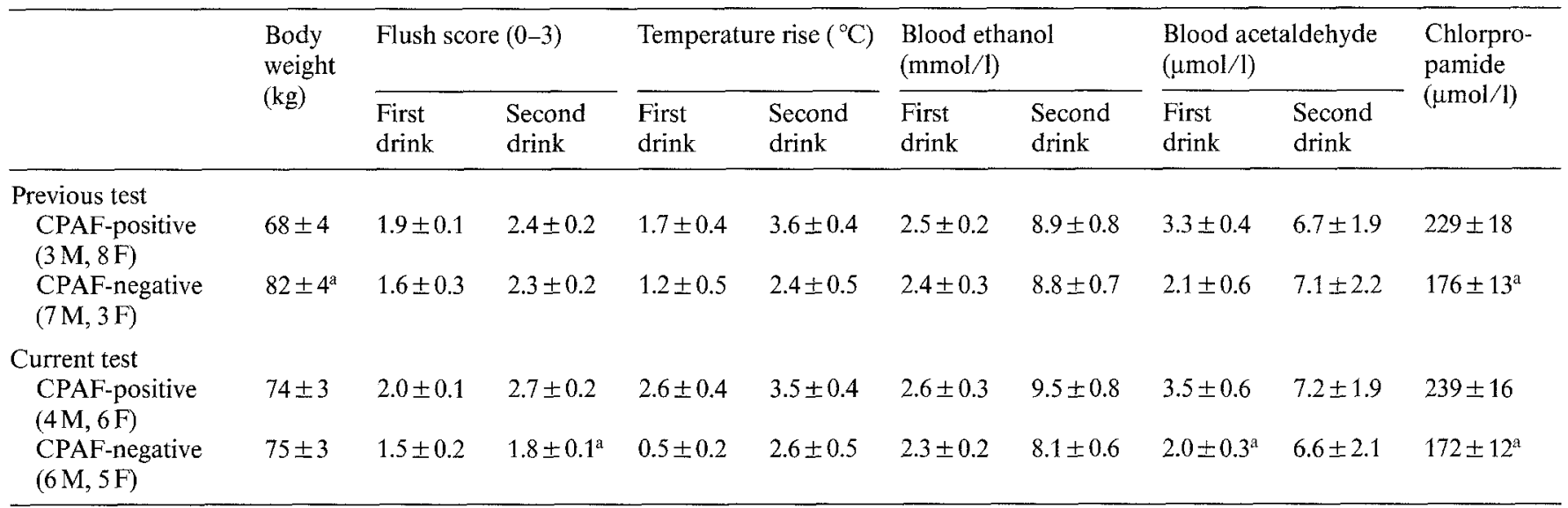

Results expressed as mean \pm SEM. ${ }^{a} p<0.05$, significance of difference between CPAF-positive and CPAF-negative subjects

hyde [8]. In addition, there are data suggesting that endogenous opiates such as metenkephalins may be implicated in CPAF [15] either directly or indirectly by interference with the rise in blood acetaldehyde.

The CPAF-positive and CPAF-negative patients had been discriminated by the use of a single-challenge CPAF test. We were, however, unable to show significant differences between the two groups regarding flush-score, rise in facial skin temperature or blood acetaldehyde levels during the current experiments, probably because of correction of the alcohol dose for body weight. The uneven sex distribution within the previously typed CPAF-positive and CPAF-negative groups similarly disappeared. However, no attempts were made to match the $\mathrm{CP}$ dose for body weight, which may explain why the previously-classified groups still differed with respect to $\mathrm{CP}$ concentrations. It is known that there is a significant correlation between $\mathrm{CP}$ dose per body weight and steady-state plasma CP levels, although individual variation is also notable [16]. There is increasing evidence that the $\mathrm{CP}$ concentration is critical for the flush [17, 18]. Melander et al. [18] reported a $42 \%$ prevalence of CPAF after a single dose of $\mathrm{CP}$, whereas the prevalence rose to $90 \%$ during $\mathrm{CP}$ maintenance therapy. Changing $\mathrm{CP}$ concentrations could make CPAF-negative patients CPAF-positive and vice versa.

Previous reports have suggested that CPAF is independent of the alcohol dose although some subjects can flush with alcohol alone [11, 19]. However, the significantly increased flushing rate after the greater alcohol dose emphasizes the critical role of the amount of alcohol given in determining the flush. Since the patients with lower body weight achieve higher blood alcohol concentrations, these patients should be more prone to flush after pretreatment with CP. Although these patients in fact may represent alcohol 'flushers', in practice it seems difficult to differentiate between chlorpropamide-alcohol flushers and subjects who flush from al- cohol alone. In the face of these findings, body-weightmatching of the alcohol dose is essential for the test.

During the current experimental conditions CPAFpositive and CPAF-negative patients clearly differed with respect to plasma CP and blood acetaldehyde concentrations. The reasons for differences in plasma $\mathrm{CP}$ levels are not known, but factors like interindividual variability in body composition or in genetic ability in handling of CP may be involved.

In conclusion, our findings support the view that CPAF is caused by inhibition of the enzyme aldehyde dehydrogenase resulting in increased acetaldehyde levels in blood. The study also presents evidence that pharmacokinetics of $\mathrm{CP}$ and alcohol are critical for the flush. Changing of the experimental conditions, and thereby the CP or alcohol concentrations, can modify the reaction to the test.

Acknowledgements. We wish to thank Miss S.Välimaa and Mrs. H. Salohalla for their expert technical help. The chlorpropamide (Melormin) and placebo tablets were kindly supplied by Lääke Oy, Turku, Finland. This study was supported by grants from the Finnish Diabetes Research Foundation and Finska Läkaresällskapet.

\section{References}

1. Fitzgerald MG, Gaddie R, Malins JM, O'Sullivan DJ (1962) Alcohol sensitivity in diabetics receiving chlorpropamide. Diabetes 11 : $40-43$

2. Leslie RDG, Pyke DA (1978) Chlorpropamide-alcohol flushing: a dominantly inherited trait associated with diabetes. Br Med J II: $1519-1521$

3. Leslie RDG, Barnett AH, Pyke DA (1979) Chlorpropamide-alcohol flushing and diabetic retinopathy. Lancet 1: 997--999

4. Barnett AH, Pyke DA (1980) Chlorpropamide-alcohol flushing and large-vessel disease in non-insulin dependent diabetes. $\mathrm{Br}$ Med J 281: 261-262

5. Jerntorp P, Almér L-O (1981) Chlorpropamide-alcohol flushing in relation to macroangiopathy and peripheral neuropathy in noninsulin dependent diabetes. Acta Med Scand (Suppl) 656:33-36 
6. Köbberling J, Bengsch N, Brueggeboes B, Schwack H, Tillil H, Weber M (1980) The chlorpropamide alcohol flush. Lack of specificity for familial non-insulin dependent diabetes. Diabetologia 19: 359-363

7. Harris M, Leslie RDG (1981) Chlorpropamide-alcohol flushing and diabetes. Diabetologia 21: 422-424 (Workshop report)

8. Jerntorp P, Öhlin H, Bergström B, Almér L-O (1981) Increase of plasma acetaldehyde. An objective indicator of the chlorpropamide-alcohol flush. Diabetes 30: 788-791

9. Barnett AH, Gonzales-Auvert C, Pyke DA, Saunders JB, Williams C, Dickenson CJ, Raulins MD (1981) Blood concentrations of acetaldehyde during chlorpropamide-alcohol flush. Br Med J 283: 939-949

10. Podgainy H, Bressler R (1968) Biochemical basis of the sulfonylurea induced antabuse syndrome. Diabetes 17:679-682

11. Jefferys DB, Keen H, Ng Tang Fui S (1981) Chlorpropamide-alcohol flush. Lancet 1: 440 (Letter)

12. Eriksson CJP, Mizoi Y, Fukunaga T (1982) The determination of acetaldehyde in human blood by the perchloric acid precipitation method: the characterization and elimination of artefactual acetaldehyde formation. Anal Biochem 125:259-263

13. Hill RE, Crechiolo J (1978) Determination of serum tolbutamide and chlorpropamide by high-performance liquid chromatography. J Chromatogr 145: 165-168

14. Strakosh CR, Jefferys DB, Keen H (1980) Blockade of chlorpropamide alcohol flush by aspirin. Lancet 1:394-396
15. Medbak S, Wass JAH, Clement-Jones V, Cooke ED, Bowcock SA, Cudworth AG, Rees LH (1981) Chlorpropamide-alcohol flush and circulating met-enkephalin: a positive link. Br Med J 283: 937-939

16. Huupponen R, Viikari J, Saarimaa H (1982) Chlorpropamide and glibenclamide serum concentrations in hospitalized patients. Ann Clin Res 14: 119-122

17. Jerntorp O, Almér L-O, Melander A (1981) Is the blood chlorpropamide concentration critical in chlorpropamide-alcohol flush? Lancet 1: 165-166

18. Melander A, Jerntorp P, Almér L-O, Öhlin H, Wåhlin-Boll E (1982) Plasma chlorpropamide: a critical factor in chlorpropamide-alcohol flush. Br J Clin Pharmacol 14: $579 \mathrm{P}$

19. Pyke DA, Johnston C (1982) Commentary on Wilkin's paper. Metabolism 31: 955-958

Received: 7 January 1983

and in revised form: 31 October 1983

Dr. L. Groop

Fourth Department of Medicine

University of Helsinki

Unioninkatu 38

SF-00170 Helsinki 17

Finland 